\title{
The Implementation of Jigsaw Type Cooperative Learning Model to Improve Student Learning Outcomes of Senior High School Seulimun in Aceh Besar Regency
}

\author{
Ismail \\ Universitas Iskandar Muda, Aceh, Indonesia \\ ismail.unida@gmail.com
}

\begin{abstract}
Application of Jigsaw Cooperative Learning Model to Improve Learning Outcomes of Social Science Learning in $11^{\text {th }}$ grade social studies (IPS-2) Senior High School Seulimum Aceh Besar Regency. The aim of the research is to improve student learning outcomes in learning Social Sciences in $11^{\text {th }}$ grade IPS-2 Senior High School Seulimum Aceh Besar Regency in the 2017/2018 school year by using Jigsaw cooperative learning, the subjects in this study were all students of $11^{\text {th }}$ grade IPS-2 Senior High School Seulimum Aceh Besar Regency in the 2017/2018 school year as many as 34 people. The research conducted was a class action research (Classroom Action Research) which was conducted for (3) months, from March to May, in 2 cycles, which became. Each cycle consists of 4 stages, namely planning, action, observation, and reflection. The research data were obtained through learning outcomes tests, observations, interviews and documentation studies. The data analysis technique used in the study was qualitative descriptive analysis. The validity of the data uses the technique of triangulation of data sources. The conclusion of the study is the application of Jigsaw cooperative learning can improve the activities and learning outcomes of students in learning Social Sciences in $11^{\text {th }}$ grade IPS-2 Senior High School Seulimum Aceh Besar Regency in the academic year 2017/2018. The results of observations showed the average indicator of student learning activities in learning Social Sciences in the first cycle was $63.29 \%$ and in the second cycle was $87.85 \%$. From cycle I to cycle II it increased by $24.56 \%$. The results of knowledge test material excretion system in humans also increased in the first cycle was 65.67 and in the second cycle 80.51, from cycle I to cycle II increased by 14.84. I was 78.41 and in the second cycle 81.78, from cycle I to cycle II increased by 3, 37. Likewise the teacher's performance in the learning process increased from cycle I by $61.0 \%$ and in the second cycle $83.50 \%$ increased by 22.50 .
\end{abstract}

Keywords

jigsawlearning model; cooperative learning; outcomes

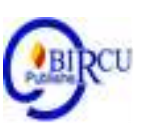

\section{Introduction}

Application of Jigsaw Cooperative Learning Model to Improve Learning Outcomes of Social n RI Law Number 14 of 2005 concerning the National Education System, and Republic of Indonesia Government Regulation Number 74 of 2008 concerning teachers state that teachers are "professional educators". Therefore the government always strives to perfect the teacher's professional competence because in daily practice teachers seem to prioritize teaching mechanically and forget the task of educating ". Teachers as educators have an important role in efforts to improve the quality of education. One important role of the teacher is to create conditions or environmental systems that support and allow for an active and interesting learning process for students, which in turn can improve learning outcomes. 
Improvement or improvement of student learning outcomes may not be coercive or through the help of other parties, but the teacher finds a way to make students become active learning. Student activeness can be raised in various ways, one of which is to innovate learning methods and models.

According to Zaini (2010: 27) Learning Jigsaw cooperative model is an interesting strategy to use if the material to be studied can be divided into several parts and the material does not require the order of delivery. The advantage of this strategy is that it can involve all students in learning and at the same time teach others.

The learning model has a very important role in the process of teaching and learning activities and is one of the main parameters of the success of teachers in teaching. According to Kiswoyo in Ekawarna (2011: 62) states "The model in the context of learning is defined as a pattern of teacher-student activities to deliver changes that occur in students as a result of teaching and learning. Furthermore, Joni in Ekawarna added that the Model is a teaching and learning strategy, or teaching strategy. Meanwhile, according to Branly in Ekawarna (2011: 62) defines the learning model as a blueprint (basic framework) that can be used as a guide to make or arrange learning preparations and then implement them. Learning models can be used as teaching strategies that essentially try to explain the components of a set of teaching materials and procedures that will be used to present, describe, set examples, and provide training to students in order to achieve certain goals. The learning model used by the teacher greatly influences the achievement of learning goals so the teacher needs to choose the right learning model from many models. The choice of learning model is not only based on habits, but on how to make students become active and have high learning interest.

The results of observations in 11th grade IPS-2 Senior High School Seulimum Aceh Besar Regency showed that learning Social Sciences in Class XI IPS.3 used a conventional model. The learning model that is always the same on every subject matter makes $11^{\text {th }}$ grade IPS-2 becomes passive. $11^{\text {th }}$ grade Social studies 2 can be said to be passive during the learning process because of the overall students, more than $50 \%$ show passive conditions. The passive condition of students is sleepy by $11.90 \%$, crowded by $9.52 \%$, lazy by $16.67 \%$, and not paying attention by $16.67 \%$. Another passive attitude is that more than $30 \%$ of students do not open textbooks during the learning process. Students do not ask the teacher when given the opportunity but are unable to answer when asked a question at the end of the lesson. The results of the distribution of questionnaires in the initial conditions showed low student interest in learning, which amounted to 68.45. The activeness and interest of students in following the learning process is low causing low learning outcomes obtained by students. Further identification is through the results of initial ability tests on the subject of excretion system in humans and efforts to overcome them with an average value of 53.45 and have not yet reached the Minimum Learning Mastery Standards (SKBM) of Social Sciences that have been set by Senior High School in Aceh Besar. This is shown from 34 students who took the initial ability test, 25 students $(73.53 \%)$ scored below the KKM limit. These conditions indicate that $11^{\text {th }}$ grade IPS-2 requires a step of improvement in the learning process.

One solution that can be taken by teachers to improve student learning outcomes is by applying modeling to teaching and learning activities through cooperative learning with jigsaw type. The key to success in learning strategies for jigsaw type is interdependence. Each student relies on group members to provide the information needed. In terms of mastering more complete learning material each student does it in an expert group. According to Chotimah (2009: 70) argues "Jigsaw type learning strategies foster a strong sense of self confidence that they are able to be a source of learning for their friends".

The use of cooperative learning models jigsaw type of subject matter excretion system in this research method, is expected to be one of the variations of Social Sciences learning 
models that can improve the learning outcomes of Social Sciences $11^{\text {th }}$ grade IPS- 2 students. Senior High School Seulimum Aceh Besar Regency. From the background of the above problems motivate researchers to carry out Classroom Action Research (CAR) in $11^{\text {th }}$ grade IPS-2 Senior High School Seulimum Aceh Besar Regency Aceh Utaradengan titled "Application of the Jigsaw Cooperative Learning Model to Improve Learning Outcomes of Social Sciences Human Excretion Material in $11^{\text {th }}$ grade IPS-2 Student of Senior High Seulimum Aceh Besar Regency".

\section{Research Methods}

\subsection{Research Settings}

This Classroom Action Research (PTK) setting includes; place of research, time of study, and PTK cycle, as follows:

\subsection{Place of Research}

This Classroom Action Research (CAR) was carried out at SMA Seulimum Aceh Besar District for Social Sciences subjects. Selection of this school: First, because the researcher is one of the Social Sciences teacher at the school. The second aims to improve and enhance the learning process of the Social Science learning process.

\subsection{Research Subject}

In this Classroom Action Research (CAR) which is used as the subject is a $11^{\text {th }}$ grade IPS-2 Student of Senior High School Seulimum, Aceh Besar Regency, in the 2017/2018 academic year, amounting to 34 students, consisting of 4 (four) men and 30 (thirty) women, and Social Sciences teacher teaching in the class.

\subsection{Source of Data}

The research data used includes information about the state of students seen from the qualitative aspects that are supported by quantitative aspects. Preliminary research data in the form of observations are guided by observation sheets, giving affective questionnaires that show student interest and the results of initial ability tests on excretion material in humans. The qualitative research results referred to are descriptions of the assessment of learning outcomes from the subject matter of the excretion system in humans and are supported by quantitative data in the form of assessment results of students' daily observation sheets, questionnaire assessments, and grades obtained by students from cognitive assessment of the subject matter of excretion systems in humans. These results are used to determine whether the applied learning model is able to improve student learning outcomes in Social Sciences.

\subsection{Data Collection Techniques}

Data collection is done in two stages. In the first stage collecting data about student learning outcomes and the second stage collecting data on the activeness and seriousness of students and the ability of teachers to use Jigsaw Cooperative learning models during learning activities. Data analysis technique is done by:

\section{a. Descriptive Analysis}

Destructive analysis is intended to describe the data of research results. 


\section{b. Analysis of research data}

Learning outcomes, student activeness and teacher ability data are calculated using the percentage formula.

$$
N=\frac{\sum S}{\sum \max } \times 100
$$

Information :

$\mathrm{N}=$ Value by stretch $1-100$

$\sum \mathrm{S}=$ Number of scores obtained by students

$\sum \max =$ The maximum number of scores to be obtained

The learning outcomes obtained are interpreted in the form of qualitative categories. The qualitative categories used were adapted from the Ministry of National Education (2002) in Putra (2009), namely with the following conditions below,

$$
\begin{array}{ll}
-0-55 & =\operatorname{Low}(\mathrm{D}) \\
-56-70 & =\text { Enough }(\mathrm{C}) \\
-71-85 & =\operatorname{Good}(\mathrm{B}) \\
-86-100= & \text { Very Good }(\mathrm{A})
\end{array}
$$

\section{Discussion}

\subsection{Research Data Description}

This section presents the characteristics of the dependent variable in the form of student learning outcomes taught by cooperative learning models of jigsaw type material in the human excretion system of students in $11^{\text {th }}$ grade IPS-2 students Senior High School

\begin{tabular}{|c|c|c|c|c|c|}
\hline No & Value Score & Category & Pre-cycle & Cycle I & Cycle II \\
\hline 1 & $86-100$ & Very Good & $9(26,47 \%)$ & $14(41,18 \%)$ & $19(55,88 \%)$ \\
\hline 2 & $70-85$ & Good & $7(20,59 \%)$ & $9(26,47 \%)$ & $11(32,35 \%)$ \\
\hline 3 & $55-69$ & Enough & $10(29,41 \%)$ & $7(20,59 \%)$ & $4(11,76 \%)$ \\
\hline 4 & $0-55$ & Low & $8(23,52 \%)$ & $4(11,76 \%)$ & 0 \\
\hline & & Total & $34(100 \%)$ & $34(100 \%)$ & $34(100 \%)$ \\
\hline
\end{tabular}
Seulimum Aceh Besar Regency analyzed statistically descriptive. The data presented in the form of results obtained after the test at the end of the learning process both in the pre-cycle, cycle I and cycle II.

Table 1. Student Learning Outcomes Excretion material in humans in each cycle

From the table it appears that the acquisition of student scores has increased in each cycle. In pre-cycle students who complete learning or reach the minimum students' completeness criteria (KKBM) are only 16 students (47.06\%), and 18 students who are not yet complete (52.94\%). In the first cycle students who completed or reached the minimum learning completeness criteria (KKBM) were 23 students $(67.64 \%)$, and 11 students $(32.35 \%)$ were incomplete. While in cycle II students who achieved the minimum learning completeness criteria (KKBM) 30 students $(88.24 \%)$ and those who had not yet completed or had not yet reached the minimum learning completeness criteria (KKBM) 4 students.

From the results of tests in the first cycle and second cycle showed an increase in the number of students who reached the minimum learning completeness criteria (KKBM), from 18 students $(52.94 \%)$ in the first cycle, whereas in the second cycle students who had completed the learning had reached the KKBM 30 students $(88.24 \%)$ means that there were an increase of 12 students (32.35\%). This increase is due to students being taught the Jigsaw 
type cooperative learning model so that the learning activities of students are actively digging for information related to the material being studied.

The results of the observation sheet observations on student learning activities related to aspects; crafts, participation / activeness, responsibility, cooperation and courage in each cycle have increased average scores. The acquisition of the average value of each cycle can be seen in table 2 .

Table 2. Acquisition The average value of student activities in Learning Activities per cycle

\begin{tabular}{|l|l|c|c|c|}
\hline No & \multicolumn{1}{|c|}{ Aspect } & Cycle I(\%) & Cycle II(\%) & Enhancement (\%) \\
\hline 1 & Diligent & 62,29 & 89,43 & 27,14 \\
\hline 2 & $\begin{array}{l}\text { Participation / } \\
\text { activeness }\end{array}$ & 59,35 & 88,79 & 29,44 \\
\hline 3 & Responsible & 57,14 & 87,46 & 30,32 \\
\hline 4 & Cooperation & 67,14 & 86,95 & 19,81 \\
\hline 5 & Courage & 70,51 & 86,61 & 16,10 \\
\hline & Average & $\mathbf{6 3 , 2 9}$ & $\mathbf{8 7 , 8 5}$ & $\mathbf{2 4 , 5 6}$ \\
\hline
\end{tabular}

From the table it can be seen that the average value of students' activeness in the process of learning activities in the first cycle was $63.29 \%$ while in the second cycle was $87.85 \%$, meaning an increase of $24.56 \%$.

The research that has been carried out is Classroom Action Research (CAR) which aims to find out the improvement of students' Social Science learning outcomes on the material of human excretion using a jigsaw cooperative learning model. Student learning outcomes are discussed further to assess the role of research methods in the learning process.

The process of implementing Social Studies learning in Senior High School Seulimum Aceh Besar Regency Regency uses a jigsaw cooperative learning model. The learning model is a good learning model for use on material that has sub-subject material, but students become less active in participating in learning activities. Students do not ask when given an opportunity and also do not answer when given a question. Research with a jigsaw cooperative learning model on the material of the human excretion system is a step of learning variation that is carried out collaboratively as a follow-up to classroom observations. The application of the Jigsaw cooperative learning model of human excretion material has brought changes to the learning outcomes and activities of $11^{\text {th }}$ grade IPS- 2 .

The results of the assessment of student learning activities using a cooperative learning model jigsaw type excretion material in humans showed a significant increase of (20.59\%), where the results of Social Sciences student learning in the first cycle that reached the minimum learning completeness criteria (KKBM) that have been set 70 as many as 23 students $(67,65 \%)$, while at the end of the second cycle students whose value of the minimum learning completeness criteria (KKBM) after achieving the Minimum Learning Completion Standards (SKBM) 30 students (88.24\%) and established indicators of success by $80 \%$ so that research can be stopped in the second cycle. The description of the results of the discussion above as a whole has proven that the application of cooperative learning jigsaw models of excretion system material in humans can improve student learning outcomes in Social Sciences.

Furthermore, the acquisition of the affective domain of students in the learning process which is assessed using observation sheets on the craft, participation / activeness, responsibility, cooperation, and courage also increased. The percentage of achievement results on the average value of the activeness of students in the first cycle was $63.29 \%$, while 
in the second cycle was $87.85 \%$. From these data shows there is an increase in student activity by $24.56 \%$. To more clearly increase student learning outcomes and activities during learning using the Jigsaw learning model excretion material in humans in cycle I and cycle II can be seen in figure 1 .

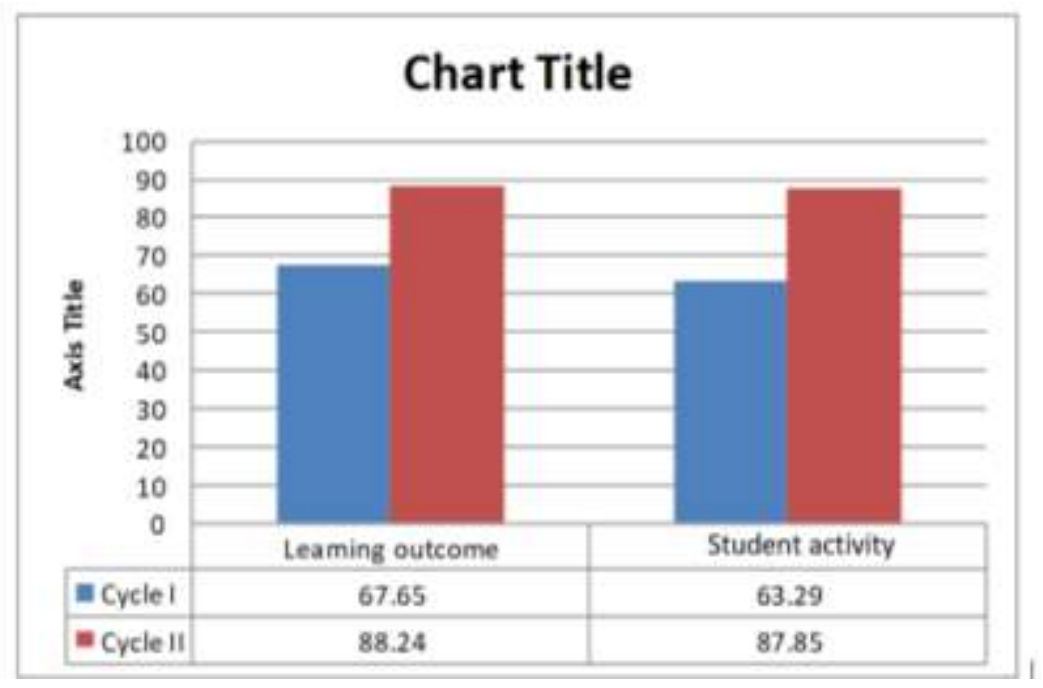

Figure 1. The Improvement of Learning Outcomes and Student Activities Cycle I and Cycle II

\section{Conclusion}

Based on the results of classroom action research that has been done in $11^{\text {th }}$ grade IPS-2 students Senior High School Seulimum Aceh Besar Regency, it can be concluded that

1. Learning using a jigsaw cooperative model can improve student learning outcomes in Social Sciences learning.

2. There is an increase in student activity in the learning process from the first cycle $63.29 \%$ to $87.25 \%$ in the second cycle, meaning the average increase of 24.56 .

Based on Classroom Action Research conducted in $11^{\text {th }}$ grade IPS-2 students Senior High School Seulimum Aceh Besar Regency, there are several suggestions, including:

1. To the teacher

2. Teachers pay more attention to the right teaching strategies that will be applied in the learning process that is able to increase student motivation in learning. One teaching strategy that can be used is Jigsaw cooperative learning.

3. To the students

a. Students can be more active in the learning process, not ashamed to ask questions when they feel they don't understand a material, and are not reluctant in giving opinions, suggestions or criticisms in the discussion process in teaching and learning activities.

b. Students do not only depend on the material provided by the teacher, but must also be active in finding material information from other relevant and supportive sources.

c. Students are motivated to learn.

4. To the school

There is a need for guidance to Social Sciences Social Sciences teachers to pay more attention to the right teaching strategies that will be applied in the learning process that is able to increase student motivation in Social Science learning, especially learning innovations using Jigsaw cooperative learning 


\section{References}

Abdul Majid. (2007). Perencanaan Pembelajaran Mengembangkan Standar Kompetensi Guru. Bandung: Remaja Rosdakarya

Anita Lie. (2008). Mempraktekkan cooperative learning di ruang kelas. Jakarta: Gramedia.

Dimyati dan Mujiono. (1999). Belajar dan Pembelajaran. Jakarta: Depdikbud dan Rineka Cipta.

Doymus, Kemal. (2009). Effects of Two Cooperative Learning Strategies on Teaching and Learning of Thermochemistry. World Applied Sciences Journal. IDOSI. Vol 7 (1): 3442.

Ekawarna. (2011). Penelitian Tindakan Kelas. Jakarta. Gaung Persada.

Gene L.Wilkinson. (1984). Media dalam Pembelajaran, Penelitian Selama 60 Tahun. Jakarta: Rajawali.

Hamzah B Uno. (2008). Teori Motivasi dan Pengukurannya Analisis di Bidang Pendidikan. Jakarta: Bumi Aksara.

Hisyam Zaini, Bermawy Munthe dan Sekar Ayu Aryani. (2007).Strategi Pembelajaran Aktif.Yogyakartya: CSTD.

Ike Nurfadilah. (2006). Efektifitas Penggunaan Metode Jigsaw Learning Dalam Pembelajaran Agama Islam (PAI) di SMP Negeri 13 Malang. (online) (http://sukses-skripsi.co, diakses 15 Juni 2010).

Isjoni dan Mohd.Arif.Hj.Ismail. (2008). Model-model Pembelajaran Mutakhir Perpaduan Indinesia-Malaysia.Yogyakarta: Pustaka Pelajar

Istamar Syamsuri. (2006). Ilmu Sosial untuk SMA Kelas XII Semester I. Jakarta: Erlangga.

Ivor K Davis. (1987). Pengelolaan Belajar. Jakarta: Rajawali Press.

Kunandar. (2003). Guru Profesional. Jakarta: Rajawali Press

Lexy J Moleong. (2005). Metodologi Penelitian Kualitatif. Bandung: Remaja Rosadakarja

Mardalis. (1990). Metode Penelitian Suatu Pendekatan Proposal. Jakarta: Bumi Aksara.

Mattew B Miles \& A. Michael Huberman. (1992). Analisa Data Kualitatif: Buku Sumber Tentang Metode- metode Baru. Jakarta: UI Press.

Mel Siberman. (2009). Active Learning: 101 Strategi Pembelajarn Aktif. Yogyakarta: Pustaka Insan Madani.

Mubbin Syah. (2005). Psikologi Pendidikan Dengan Pendekatan Baru. Bandung: Remaja Rosdakarya.

Made Wena. (2009). Strategi Pembelajaran Inovatif Kontemporer. Jakarta: Bumi Aksara. 